\title{
Karakteristik Karkas Ayam Broiler Fase Finisher yang Diberi Ekstrak Daun Jambu Mete (Anacardium occidentale Linn.) di dalam Air Minum
}

\section{Carcass characteristics in finisher-Broiler Chickens by Supplementation of Cashew Leaf Extract (Anacardium occidentale Linn.) in Drinking Water}

\author{
Mohammad Alghifari Syafaat', Edi Erwan ${ }^{1 *}$, Jully Handoko' \\ ${ }^{1}$ Program Studi Peternakan, Universitas Islam Negeri Sultan Syarif Kasim Riau \\ *corresponden author: erwan_edi@yahoo.com
}

\begin{abstract}
Diterima : 07 Agustus 2021
Disetujui $\quad: 21$ Agustus 2021

Diterbitkan : :31 Agustus 2021
\end{abstract}

\begin{abstract}
Abstrak: Daun Jambu mete (Anacardium occidentale Linn) merupakan salah satu tumbuhan yang berpotensi menjadi ramuan herbal disebabkan beberapa senyawa yang penting diantaranya mengandung asam anakardiol, asam elagat, flavonoid, kardol, tanin-galat, senyawa fenol, dan metil kardol. Adapun tujuan penelitian ini yakni untuk mengetahui pengaruh pencampuran ekstrak daun jambu mete (EDJM) di dalam air minum terhadap karakteristik karkas ayam broiler meliputi bobot badan akhir, bobot karkas, persentase bobot karkas, bobot lemak abdominal dan persentase bobot lemak abdominal. Total jumlah ayam broiler yang digunakan adalah 8o ekor yang dilakukan pengacakan dengan 5 perlakuan dan 4 ulangan serta setiap ulangan terdiri dari 4 ekor ayam. Penelitian ini menggunakan Rancangan Acak Lengkap (RAL) dengan perlakuan yang meliputi Po (o\% EDJM/L air minum), $P_{1}$ (5\% EDJM/L air minum), $P_{2}$ (90\% air minum + 10\% EDJM), $P_{3}$ (85\% air minum + 15\% EDJM) dan $P_{4}(80 \%$ air minum $+20 \%$ EDJM). Parameter yang diukur adalah bobot badan akhir, bobot karkas, persentase karkas, bobot lemak abdominal dan persentase lemak abdominal. Hasil penelitian menunjukkan bahwa bobot lemak abdominal dan persentase lemak abdominal secara signifikan $(P<0,05)$ menurun dengan pemberian EDJM hingga kadar $20 \%$. Namun demikian, pemberian EDJM tidak berpengaruh nyata $(P>, 05)$ terhadap bobot badan akhir, bobot karkas dan persentase karkas. Dapat disimpulkan bahwa karakteristik karkas ayam broiler khususnya dalam bobot lemak abdominal dan persentase lemak abdominal dapat menurun dengan pemberian EDJM dalam air minum sampai level $20 \%$.
\end{abstract}

Kata Kunci: Ayam broiler, ekstrak daun jambu mete, bobot karkas, bobot lemak abdominal dan persentase bobot lemak abdominal

\begin{abstract}
Cashew leaves (Anacardium Occidental Linn) is one of the plants that can be used as herbal potion because it contains flavonoids, gallic tannins, anacardiol acid, ellagic acid, phenolic compounds, cardol and methyl cardol. The aim of present study was to investigate the effect of inclusion cashew leaf extract (CLE) in drinking water on carcass characteristics included final body weight, abdominal fat weight, carcass weight percentage and abdominal fat percentage in finisher-broiler chickens. The total of 80 broiler chickens were used in this research and divided randomly based on a Completely Randomized Design (CRD) with 5 treatments and 4 replications while each replication consisted of 4 animals. Treatments Po was o\% CLE in $1 L$ of drinking water; treatment $P_{1}$ was $5 \%$ CLE in $1 \mathrm{~L}$ of drinking; treatment $P_{2}$ was $10 \%$ CLE in $1 \mathrm{~L}$ of drinking water; treatment $P_{3}$ was $15 \%$ CLE in $1 \mathrm{~L}$ of drinking water and treatment $P_{4}$ was $20 \%$ CLE in 1 L of drinking water. The results showed that abdominal fat weight and abdominal fat percentage were significantly $(P<0.05)$ decreased by the inclusion CLE up to $20 \%$ in drinking water but final body weight carcass weight and carcass percentage were not significantly different. It is concluded that carcass characteristics in terms of abdominal fat weight and abdominal fat could be improved by the inclusion of CLE in drinking water up to $20 \%$ in broiler chickens.
\end{abstract}

Keywords: Broiler chicken, cashew leaf extract, final body weight, carcass weight percentage, abdominal fat weight and abdominal fat percentage 


\section{Pendahuluan}

Ayam broiler memiliki peranan yang penting dalam pemenuhan kebutuhan protein hewani masyarakat. Kebutuhan terhadap daging ayam semakin bertambah seiring dengan meningkatnya penghasilan dan kesadaran penduduk akan pentingnya protein hewani. Ayam broiler merupakan ayam ras unggas pedaging yang mampu tumbuh cepat sehingga dapat menghasilkan daging dalam waktu relatif singkat 5- 7 minggu [1]. Meningkatnya kesadaran masyarakat akan kebutuhan zat gizi menyebabkan konsumsi terhadap bahan makanan hewani yaitu sekitar 20,20 gram/kap/hari [2], akan tetapi masyarakat masih banyak berpandangan bahwa mengonsumsi ayam dapat menyebabkan berbagai penyakit, ini dikarenakan kandungan lemak daging ayam yang tinggi yaitu 25 gram/10o gram [3]. Ayam broiler merupakan jenis ayam hasil rekayasa genetik yang memiliki produktivitas yang tinggi dalam menghasilkan daging dibandingkan dengan jenis ayam lainnya. Pertumbuhan ayam broiler yang cepat juga diikuti dengan pertumbuhan lemaknya yang cepat [4].

Untuk meningkatkan produktivitas ayam broiler diperlukan pakan dengan penambahan antibiotik. Namun penggunaan antibiotik menimbulkan residu yang mengakibatkan resistensi bakteri dan residu pada hasil ternak tersebut. Konsumsi pangan asal hewan seperti daging ayam yang mengandung residu antibiotika memiliki banyak dampak negatif bagi kesehatan yaitu reaksi alergi, toksisitas, mempengaruhi flora usus, respon imun, dan resistensi terhadap mikroorganisme. Selain berbahaya bagi kesehatan, residu antibiotik juga dapat pengaruh terhadap lingkungan dan ekonomi [5]. Alternatif yang dapat dilakukan sebagai pengganti antibiotik yaitu penggunaan tanaman herbal [6]. Salah satu alternatif pakan tambahan alami yang berfungsi sebagai ramuan herbal adalah daun jambu mete (Anacardium occidentale Linn).

Jambu mete merupakan tanaman yang tumbuh di Indonesia dan memiliki berbagai manfaat terutama dalam bidang kesehatan. Ekstrak etanol daun jambu mete memiliki senyawa antioksidan seperti golongan dari kelompok senyawa fenol dan flavonoid [7]. Kandungan senyawa tanin, saponin, resin, alkaloid dan flavonoid pada ekstrak daun jambu mete juga berfungsi sebagai antibiotik [8]; [9].

Penelitian [10] menunjukkan bahwa ekstrak etanol daun jambu mete dapat berperan sebagai antibiotik alami dengan melindungi saluran pencernaan seperti pada usus halus. Berdasarkan hasil penelitian [11] pemberian ekstrak daun jambu mete sampai kadar $20 \mathrm{~g} / \mathrm{kg}$ pakan menunjukkan perbedaan yang signifikan dalam meningkatkan berat badan ayam jawa super pada umur 6 hari sampai 15 hari.
Namun demikian, belum pernah dilakukan penelitian menggunakan ekstrak daun jambu mete pada ayam broiler. Untuk memudahkan implementasi peternakan penulis tertarik untuk menggunakan ekstrak daun jambu mete (Anacardium occidentale Linn) pada air minum terhadap karkas ayam broiler.

\section{Metode}

\subsection{Ternak dan Ransum}

Ternak yang digunakan dalam penelitian ini adalah ayam pedaging berumur 1 hari (DOC) sebanyak 8o ekor tanpa perbedaan jenis kelamin (Unsexing) dari PT. Charoen Pokphand Tbk. Ransum yang digunakan dalam penelitian ini berupa pakan komersial untuk fase starter dan fase finisher.

\subsection{Kandang dan Peralatan}

Jumlah unit kandang yang digunakan adalah sebanyak 20 unit kandang plus 1 unit kandang tambahan sebagai cadangan untuk karantina. Luas kandang yang digunakan adalah panjang $75 \mathrm{~cm}$ x lebar $60 \mathrm{~cm}$ dan tinggi $60 \mathrm{~cm}$. Setiap unit kandang diisi 4 ekor ayam. Selain peralatan untuk perkandangan, peralatan yang digunakan termometer ruang untuk mengukur suhu lingkungan kandang, lampu pemanas, timbangan untuk menimbang berat badan ayam pedaging dan sisa konsumsi ransum, gelas ukur untuk mengukur konsumsi air minum, semprotan untuk desinfeksi, litter, plastik dan kertas koran bekas untuk menampung feses ayam pedaging, nampan, kain lap, alat tulis dan kamera handphone. Tempat Penelitian ini adalah di UIN Agriculture Research and Development Station (UARDS), Fakultas Pertanian dan Peternakan Universitas Islam Negeri Sultan Syarif Kasim Riau yang dilaksanakan mulai bulan Januari sampai Februari 2021.

\subsection{Pembuatan Ekstrak daun Jambu Mete (EDJM)}

Cara pembuatannya dengan mengambil daun jambu mete yang sudah tua dan masih keadaan segar, lalu dicuci, dipotong-potong sekitar 1-2 cm, kemudian ditimbang $500 \mathrm{~g}$, lalu dicampurkan dengan air sebanyak 1 liter, setelah itu diblender hingga halus, dan disaring untuk mendapatkan ekstrak daun jambu mete.

\subsection{Rancangan Penelitian}

Penelitian ini menggunakan rancangan percobaan Acak Lengkap (RAL). Anak ayam brolier (DOC) sebanyak 80 ekor secara acak dengan 5 perlakuan dan 4 kali ulangan. Pemeliharaan ayam dari umur 1 sampai 28 hari. Adapun model perlakuan yang diberikan dalam penelitian ini sebagai berikut:

$\mathrm{Po}=0 \%$ EDJM dalam 1 liter air

$\mathrm{P} 1=5 \%$ EDJM dalam 1 liter air 


\section{$\mathrm{P}_{2}=10 \%$ EDJM dalam 1 liter air}

$\mathrm{P}_{4}=20 \%$ EDJM dalam 1 liter air

$\mathrm{P}_{3}=15 \%$ EDJM dalam 1 liter air

Tabel 1. Komposisi Nutrisi Ransum Komersial

\begin{tabular}{lcc}
\hline \multirow{2}{*}{ Zat Nutrisi } & \multicolumn{2}{c}{ Jenis Ransum } \\
\cline { 2 - 3 } & Fase Starter(\%) & Fase Finisher(\%) \\
\hline Protein & $\mathbf{2 1 , 0 - 2 2 , 0}$ & Max 8,0 \\
Abu & Max 8,0 & Min 4,5 \\
Lemak & Min 4,3 & Max 6,0 \\
Serat Kasar & Max 6,0 & Min 0,9 \\
Kalsium & Min 0,9 & Min o,6 \\
Phospor & Min o,6 &
\end{tabular}

Sumber: PT. Charoen Pokphand Indonesia [12].

\subsection{Peubah yang Diamati}

Peubah yang diamati pada penilitian ini Ayam ras Pedaging umur 1-28 hari adalah:

\subsubsection{Bobot Badan Akhir (g/ekor)}

Perhitungan bobot akhir dilakukan dengan cara penimbangan bobot ayam hidup pada akhir pemeliharaan [13].

\subsubsection{Bobot Karkas (g/ekor)}

Karkas ayam broiler ialah bagian dari ayam broiler hidup, setelah dipotong, dibului, dikeluarkan jeroan dan lemak abdominalnya, dipotong kepala dan leher serta kedua kakinya (ceker) [14].

\subsubsection{Persentase Karkas (\%)}

Persentase karkas dihitung dengan membandingkan bobot karkas ayam broiler dengan bobot badan akhir lalu dikalikan $100 \%$ [15]. Persentase Karkas $=$ Bobot karkas/bobot badan akhir $\mathrm{x} 100 \%$.

\subsubsection{Bobot Lemak Abdominal (g/ekor)}

Lemak abdominal merupakan salah satu komponen lemak tubuh yang terletak pada rongga perut. Bobot lemak abdominal dihitung dengan cara menimbang bobot lemak yang melekat di bagian perut ayam broiler yang meliputi ampela, dinding perut, dan kloaka.

\subsubsection{Persentase Lemak Abdominal (\%)}

Persentase lemak abdominal diperoleh dengan cara menghitung perbandingan bobot lemak abdominal dengan bobot badan akhir lalu dikalikan $100 \%$ [16]. Persentase Lemak Abdominal = Bobot Lemak Abdominal /bobot badan akhir x 100\%.

\subsection{Analisis Data}

Data diolah dengan hitungan manual dan juga data mentah (raw data) dilakukan uji Thompson untuk menghilangkan data outlier dengan menggunakan tingkat pengujian $(\mathrm{P}<0,05)$. Data yang ditampilkan adalah nilai rataan dan standar deviasi. Analisis sidik ragam digunakan untuk mengetahui pengaruh perlakuan terhadap peubah yang diamati. Jika analisis ragam menunjukkan pengaruh nyata akan dilakukan uji lanjut dengan Duncan's Multiple Range Test (DMRT)

\section{Hasil dan Pembahasan}

\subsection{Bobot Badan Akhir Ayam Broiler}

Hasil pengamatan pengaruh penambahan ekstrak daun jambu mete (EDJM) di dalam air minum terhadap bobot badan akhir ayam broiler disajikan pada Tabel 2.

Tabel 2. Rataan bobot badan akhir ayam broiler umur 28 hari yang diberi EDJM (gram/ekor)

\begin{tabular}{lc}
\hline Perlakuan & Bobot Badan Akhir \\
\hline $\mathrm{Po}=$ o\% EDJM & $1.452,00 \pm 105,19$ \\
$\mathrm{P} 1=5 \%$ EDJM & $1.477,57 \pm 151,39$ \\
$\mathrm{P}_{2}=10 \%$ EDJM & $1.454,00 \pm 123,06$ \\
$\mathrm{P}_{3}=15 \%$ EDJM & $1.425,00 \pm 168,79$ \\
$\mathrm{P} 4=20 \%$ EDJM & $1.325,88 \pm 135,16$ \\
\hline Keterangan: & \\
- EDJM = Ekstrak daun jambu mete \\
- Data yang ditampilkan adalah rata-rata \pm STDEV
\end{tabular}

Hasil analisis sidik ragam menunjukkan bahwa pemberian EDJM o\%-20\% menunjukkan pengaruh yang tidak berbeda nyata $(\mathrm{P}>0,05)$ terhadap bobot badan akhir ayam broiler. Bobot badan akhir yang tidak berbeda nyata tersebut menunjukkan bahwa sampai kadar 20\% EDJM belum mengakibatkan perubahan meskipun diberi EDJM di dalam air minum. Hal ini diduga dipengaruhi karena konsumsi ransum pada penelitian ini yang juga tidak berbeda nyata [17]. Bobot badan akhir dipengaruhi oleh pertambahan bobot badan dan konsumsi ransum [18]. Konsumsi ransum memiliki korelasi dengan pertambahan bobot badan ayam broiler [19]. Hal ini sesuai dengan pernyataan [20], bahwa salah satu faktor yang berperan penting dalam mempengaruhi 
laju pertumbuhan adalah konsumsi ransum. Apabila konsumsi ransum menurun akan menyebabkan pertambahan bobot badan menurun dimana pertambahan bobot badan memiliki korelasi dengan pencapaian bobot badan akhir [21]. Faktor yang mempengaruhi bobot potong adalah jenis kelamin, kandungan nutrien dan konsumsi pakan [13].

Selain itu faktor yang diduga menyebabkan tidak berpengaruh nyata terhadap bobot badan akhir ayam broiler yaitu pemberian EDJM yang mengandung senyawa bioaktif khususnya flavonoid sampai level $20 \%$ belum cukup optimal atau belum mencukupi dalam mempengaruhi proses metabolisme di dalam tubuh ayam broiler. Rataan bobot akhir ayam broiler pada penelitian ini berkisar antara 1.325,88 - 1.477,57 gram. Nilai rataan bobot akhir pada penelitian ini lebih rendah jika dibandingkan dengan standar berat badan ayam broiler $\mathrm{CP} 707$ dengan nilai bobot badan umur 4 minggu yaitu 1467 gram [12]. Namun nilai rataan hasil penelitian ini lebih tinggi dibandingkan dengan yang dilaporkan [22] yakni dengan pemberian ekstrak daun binahong yang juga merupakan herbal yang mengandung senyawa flavonoid dalam air minum menghasilkan rata-rata bobot hidup ayam broiler umur 28 hari berkisar antara 1.075 - 1.262,65 gram/ekor. Hasil penelitian ini tidak sesuai dengan yang dilaporkan [11] dengan penggunaan ekstrak etanolit daun jambu mete sampai level $20 \mathrm{~g} / \mathrm{kg}$ pakan menunjukan pengaruh yang berbeda nyata terhadap berat badan ayam jawa super selama 15 hari.

\subsection{Bobot Karkas Ayam Broiler}

Hasil pengamatan pengaruh penambahan EDJM didalam air minum terhadap bobot karkas ayam broiler disajikan pada Tabel 3.

Tabel 3. Rataan bobot karkas ayam broiler umur 28 hari yang diberi EDJM dalam air minum (gram/ekor)

\begin{tabular}{lc}
\hline Perlakuan & Bobot Karkas \\
\hline $\mathrm{Po}=$ o\% EDJM & $1.035,09 \pm 83,46$ \\
$\mathrm{P} 1=5 \%$ EDJM & $934,26 \pm 176,10$ \\
$\mathrm{P}_{2}=10 \%$ EDJM & $973,85 \pm 71,31$ \\
$\mathrm{P}_{3}=15 \%$ EDJM & $960,58 \pm 114,63$ \\
$\mathrm{P}_{4}=20 \%$ EDJM & $895,74 \pm 96,40$ \\
\hline
\end{tabular}

Keterangan:

- EDJM = Ekstrak daun jambu mete

- Data yang ditampilkan adalah rata-rata \pm STDEV

Hasil analisis sidik ragam menunjukkan bahwa pemberian EDJM o\%-20\% menunjukkan pengaruh yang tidak berbeda nyata $(\mathrm{P}>\mathrm{O}, 05)$ terhadap bobot karkas ayam broiler. Bobot karkas yang tidak berbeda nyata tersebut menunjukkan bahwa sampai kadar 20\% EDJM belum mengakibatkan perubahan meskipun diberi EDJM di dalam air minum. Hasil penelitian ini sesuai dengan yang dilaporkan [23] bahwa pemberian $6 \%$ ekstrak daun mengkudu yang juga mengandung flavonoid dalam air minum tidak memberikan pengaruh yang tidak berbeda nyata terhadap bobot karkas puyuh. Hal ini sesuai dengan pendapat [24] yang menyatakan bahwa bobot karkas berhubungan erat dengan pertumbuhan dan bobot badan akhir. Rataan bobot karkas ayam broiler pada penelitian ini berkisar antara 895,74 - 1.035,09 gram. Nilai rataan bobot karkas pada penelitian ini lebih tinggi dibandingkan dengan yang dilaporkan [22] dengan pemberian ekstrak daun binahong dalam air minum yang menyatakan bahwa rataan bobot karkas ayam broiler umur 28 hari berkisar antara 669-801,5 gram/ekor.

Hasil penelitian ini mengindikasikan bahwa pemberian EDJM 5-20\% yang mengandung zat fitokimia seperti flavonoid, alkaloid, tanin, saponin, dan terpenoid diduga belum memberikan kontribusi positif terhadap pencernaan dalam tubuh broiler untuk peningkatan konsumsi ransum sehingga bobot hidup dan bobot karkas tidak berbeda nyata dibandingkan dengan kontrol. Hal ini sesuai dengan pernyataan [25], bahwa bobot karkas selalu diimbangi bobot hidup broiler yang dipengaruhi oleh jumlah konsumsi ransum serta proses pencernaan dan penyerapan ransum secara optimal.

Faktor lainnya yang diduga menyebabkan bobot karkas antar perlakuan yang tidak berbeda nyata yaitu diduga terkait dengan ransum yang diberikan pada penelitian ini semuanya adalah menggunakan ransum komersial sehingga kandungan protein kasar dan energi metabolismenya juga sama. Pendapat ini sesuai dengan pendapat [26] bahwa ternak yang diberikan ransum yang dapat memenuhi kebutuhan nutrisi ternak secara lengkap maka juga dapat mempengaruhi kualitas karkas sehingga konsumsi dan karkasnya juga sama. Selain itu juga diduga bahwa senyawa yang terdapat dalam EDJM seperti tanin, saponin, flavonoid yang dicampurkan di dalam air minum ayam broiler tersebut masih dapat ditoleransi oleh ayam broiler, akibatnya konsumsi ransum yang tidak berbeda nyata juga mengakibatkan bobot karkas yang tidak berbeda nyata.

\subsection{Persentase Karkas Ayam Broiler}

Hasil pengamatan pengaruh penambahan EDJM di dalam air minum terhadap persentase karkas ayam broiler disajikan pada Tabel 4 .

Hasil analisis sidik ragam menunjukkan bahwa pemberian EDJM o\%-20\% menunjukkan pengaruh yang tidak berbeda nyata $(\mathrm{P}>0,05)$ terhadap persentase karkas ayam broiler. Persentase karkas yang tidak berbeda nyata tersebut menunjukkan bahwa sampai kadar $20 \%$ EDJM belum mengakibatkan perubahan meskipun diberi EDJM di dalam air minum. Penambahan EDJM sampai level $20 \%$ berpengaruh tidak nyata terhadap persentase 
karkas diduga karena hasil bobot akhir dan bobot karkas pada penelitian ini juga tidak berpengaruh nyata. Rataan persentase karkas ayam broiler pada penelitian ini berkisar antara 66,63\% - 68,86\% lebih rendah dari penelitian [27] yang menyatakan bahwa persentase karkas bagian tubuh ayam broiler berkisar antara $65-75 \%$ dari bobot hidup. Namun rataan persentase karkas ayam broiler pada penelitian ini lebih tinggi dibandingkan yang dilaporkan [28] bahwa rataan persentase berat karkas ayam broiler umur 5 minggu dengan pemberian ekstrak temulawak dan kunyit dalam ransum adalah 59-63\% dari bobot hidup. Hasil penelitian ini sama dengan yang dilaporkan [29] bahwa penambahan tepung daun salam yang juga mengandung golongan senyawa seperti flavonoid pada ransum sampai taraf $3 \%$ tidak memberikan pengaruh nyata terhadap persentase karkas ayam broiler.

Tabel 4. Rataan persentase karkas ayam broiler umur 28 hari yang diberi EDJM dalam air minum (\%)

\begin{tabular}{lc}
\hline Perlakuan & Persentase Bobot Karkas \\
\hline Po $=$ o\% EDJM & $68,86 \pm 1,78$ \\
$\mathrm{P}_{1}=5 \%$ EDJM & $66,63 \pm 1,49$ \\
$\mathrm{P}_{2}=10 \%$ EDJM & $67,89 \pm 1,63$ \\
$\mathrm{P}_{3}=15 \%$ EDJM & $67,46 \pm 2,72$ \\
$\mathrm{P}_{4}=20 \%$ EDJM & $67,54 \pm 1,78$ \\
\hline
\end{tabular}

Keterangan:

- EDJM = Ekstrak daun jambu mete

- Data yang ditampilkan adalah rata-rata \pm STDEV

Hasil penelitian ini mengindikasikan bahwa penggunaan EDJM belum mampu mengubah persentase karkas ayam broiler secara signifikan. Persentase karkas berhubungan dengan jenis kelamin, umur dan bobot hidup [30]. Karkas meningkat seiring dengan meningkatnya umur dan bobot hidup. Persentase karkas yang dihasilkan pada penelitian ini masih berada dalam kisaran normal. Persentase karkas ayam broiler bervariasi antara 65$75 \%$ dari bobot hidup [31]. Kualitas karkas dinilai berdasarkan konformasi, perdagingan, perlemakan di bawah kulit, tingkat kebersihan dari bulu halus, derajat kemerahan dan perobekan kulit serta bebas dari tulang patah [32]. Semakin berat ayam yang dipotong, persentase karkasnya semakin tinggi.

\subsection{Bobot Lemak Abdominal Ayam Broiler}

Hasil pengamatan pengaruh penambahan EDJM di dalam air minum terhadap Bobot Lemak Abdominal ayam broiler disajikan pada Tabel $\mathbf{5}$.

Hasil analisis sidik ragam menunjukkan bahwa pemberian EDJM o\%-20\% menunjukkan pengaruh yang berbeda nyata $(\mathrm{P}<0,05)$ terhadap bobot lemak abdominal ayam broiler. Nilai rataan bobot lemak abdominal ayam broiler tertinggi pada perlakuan $\mathrm{P} 1$ dengan EDJM 5\% sedangkan terendah pada perlakuan $\mathrm{P}_{3}$ dengan EDJM 15\% di dalam air minum. Rataan bobot lemak abdominal ayam broiler pada penelitian ini berkisar antara 8,41-10,73 gram. Nilai rataan bobot lemak abdominal pada penelitian ini lebih rendah dari pada hasil penelitian [33] dengan menggunakan daun ashitaba dalam pakan berkisar 19,80-26,6o gram.

Tabel 5. Rataan bobot lemak abdominal ayam broiler umur 28 hari yang diberi EDJM dalam air minum (gram/ekor)

\begin{tabular}{lc}
\hline Perlakuan & Bobot Lemak Abdominal \\
\hline Po $=$ o\% EDJM & $16,14 \pm 7,89^{\mathrm{ab}}$ \\
$\mathrm{P} 1=5 \%$ EDJM & $21,50 \pm 6,98^{\mathrm{a}}$ \\
$\mathrm{P} 2=10 \%$ EDJM & $15,57 \pm 8,63^{\mathrm{ab}}$ \\
$\mathrm{P}_{3}=15 \%$ EDJM & $8,41 \pm 6,46^{\mathrm{b}}$ \\
$\mathrm{P}_{4}=20 \%$ EDJM & $10,73 \pm 7,98^{\mathrm{b}}$ \\
\hline
\end{tabular}

Keterangan:

- EDJM = Ekstrak daun jambu mete

- Data yang ditampilkan adalah rata-rata \pm STDEV

- Superskrip yang berbeda pada kolom yang sama menunjukkan pengaruh yang berbeda nyata $(\mathrm{P}<0,05)$

Hasil uji lanjut DMRT menunjukkan hasil perlakuan Po tidak berbeda nyata $(\mathrm{P}>0,05)$ dengan perlakuan $\mathrm{P}_{1}, \mathrm{P}_{2}, \mathrm{P}_{3}$, dan $\mathrm{P}_{4}$, diduga karena senyawa flavonoid yang terkandung di dalam EDJM belum mempengaruhi bobot lemak abdominal. Namun perlakuan $\mathrm{P}_{1}$ berbeda nyata $(\mathrm{P}<\mathrm{0}, 05)$ dengan perlakuan $\mathrm{P}_{3}$ dan $\mathrm{P}_{4}$. EDJM memiliki kandungan senyawa tanin, saponin, resin, alkaloid dan flavonoid [9]. Kandungan alkaloid EDJM mampu menghambat kinerja enzim lipase dalam saluran cerna sehingga absorbsi lemak dalam tubuh berkurang. Flavonoid termasuk senyawa fenol alami yang mampu menghambat pembentukan misel usus (lemak yang terkandung di dalam bahan konsumsi yang dicerna juga oleh asam empedu) tempat terjadinya penyerapan asam empedu yang salah satu fungsinya untuk melarutkan lemak melalui saluran empedu ke dalam usus, sehingga pada akhirnya lemak tubuh menurun [34]. Penimbunan lemak dapat terjadi karena kelebihan energi setelah digunakan untuk memenuhi kebutuhan pokok dan untuk produksi. Kelebihan energi tersebut ditransformasi menjadi senyawa lemak yang selanjutnya disimpan dalam jaringan adiposa di abdomen [35]. Nilai bobot lemak abdominal yang diperoleh pada perlakuan $\mathrm{P}_{3}$ dengan level pemberian 15\% EDJM, seiring dengan kadar kolesterol yang juga paling rendah didapatkan pada penelitian ini (Fachrurozi, un published). Seiring dengan menurunnya bobot lemak abdominal ayam broiler juga secara langsung menurunkan kadar kolestrol daging ayam broiler [36]. 


\subsection{Persentase Lemak Abdominal Ayam Broiler}

Hasil pengamatan pengaruh penambahan EDJM didalam air minum terhadap Persentase Lemak Abdominal ayam broiler disajikan pada Tabel 6.

Tabel 6. Rataan Persentase Lemak Abdominal ayam broiler umur 28 hari yang diberi EDJM dalam air minum (\%)

\begin{tabular}{lc}
\hline Perlakuan & $\begin{array}{c}\text { Persentase Lemak } \\
\text { Abdominal }\end{array}$ \\
\hline Po $=$ o\% EDJM & $1,02 \pm 0,53^{\mathrm{ab}}$ \\
$\mathrm{P}_{1}=5 \%$ EDJM & $1,54 \pm 0,46^{\mathrm{b}}$ \\
$\mathrm{P}_{2}=10 \%$ EDJM & $1,08 \pm 0,64^{\mathrm{ab}}$ \\
$\mathrm{P}_{3}=15 \%$ EDJM & $0,57 \pm 0,41^{\mathrm{a}}$ \\
$\mathrm{P}_{4}=\mathbf{2 0} \%$ EDJM & $0,82 \pm 0,63^{\mathrm{a}}$ \\
\hline
\end{tabular}

Keterangan:

- EDJM = Ekstrak daun jambu mete

- Data yang ditampilkan adalah rata-rata \pm STDEV

- Superskrip yang berbeda pada kolom yang sama menunjukkan pengaruh yang berbeda nyata $(\mathrm{P}<0,05)$

Hasil analisis sidik ragam menunjukkan bahwa pemberian EDJM o\%-20\% menunjukkan pengaruh yang berbeda nyata $(\mathrm{P}<0,05)$ terhadap persentase lemak abdominal ayam broiler. Nilai rataan persentase lemak abdominal ayam broiler tertinggi pada perlakuan $\mathrm{P}_{1}$ dengan EDJM 5\% sedangkan terendah pada perlakuan $\mathrm{P}_{3}$ dengan EDJM 15\% di dalam air minum. Rataan persentase lemak abdominal ayam broiler pada penelitian ini berkisar antara $0,57-1,54 \%$, hal ini menunjukkan bahwa nilai rataan persentase lemak abdominal pada penelitian ini lebih rendah dari pada hasil penelitian [34] dengan pemberian tepung daun jati belanda dalam pakan berkisar 1,09-2,17\% dari bobot hidup. Ditambahkan pula penelitian [37] menunjukkan persentase lemak abdominal berkisar antara 1,50$\mathbf{2 , 1 1 \%}$. Ayam broiler yang memiliki bobot lemak abdominal terbesar tidak selamanya memiliki persentase lemak abdominal yang besar pula [38]. Hal ini dikarenakan persentase lemak abdominal didapat dengan cara membandingkan bobot lemak abdominal dengan bobot badan akhir dikalikan 100\% [39]. Artinya persentase lemak abdominal ayam ras pedaging dipengaruhi oleh bobot badan akhirnya.

Hasil uji lanjut DMRT menunjukkan hasil perlakuan Po tidak berbeda nyata $(\mathrm{P}>0,05)$ dengan perlakuan $\mathrm{P}_{1}, \mathrm{P}_{2}, \mathrm{P}_{3}$, dan $\mathrm{P}_{4}$. Namun perlakuan $\mathrm{P}_{1}$ berbeda nyata $(\mathrm{P}<0,05)$ dengan perlakuan $\mathrm{P}_{3}$ dan $\mathrm{P}_{4}$. Persentase bobot lemak abdominal yang berbeda tidak nyata $(\mathrm{P}>0,05)$ menunjukkan bahwa EDJM belum berpengaruh terhadap persentase bobot lemak abdominal ayam broiler. Namun persentase bobot lemak abdominal yang berbeda nyata $(\mathrm{P}<0,05)$ menunjukkan bahwa EDJM sudah berpengaruh terhadap persentase bobot lemak abdominal ayam broiler. Hal ini membuktikan bahwa ada pengaruh penggunaan EDJM terhadap persentase lemak abdominal ayam broiler. Penurunan persentase lemak abdominal pada penelitian ini diduga disebabkan oleh kandungan zat bioaktif yang terdapat pada EDJM. Kandungan EDJM berupa senyawa tanin, saponin, resin, alkaloid dan flavonoid [8]. Kandungan alkaloid daun jati belanda mampu menghambat kinerja enzim lipase dalam saluran cerna sehingga absorbsi lemak dalam tubuh berkurang. Zat bioaktif tanin banyak terkandung di bagian daun dan mampu mengurangi penyerapan makanan di usus dengan cara mengendapkan protein mukosa yang ada dalam permukaan usus. Selain itu, faktor yang menyebabkan perlakuan yang berbeda nyata yaitu berkaitan dengan bobot hidup ayam broiler. Hal ini didukung [40] yang melaporkan bahwa pada umumnya meningkatnya bobot hidup ayam diikuti oleh meningkatnya kandungan lemak abdominal yang menghasilkan produksi daging yang tinggi.

\section{Kesimpulan}

Hasil penelitian ini menunjukkan bahwa pencampuran EDJM di dalam air minum ayam broiler hingga level 20\% dapat memperbaiki kualitas karkas ayam khususnya menurunkan bobot lemak abdominal serta persentase lemak abdominal.

\section{Referensi}

[1] Umam, M. K., H. S. Prayogi dan V. M. A. Nurgiartiningsih. 2015. Penampilan produksi ayam pedaging yang dipelihara pada sistem lantai kandang panggung dan kandang bertingkat. Jurnal Ilmu-Ilmu Peternakan. 24 (3): $79-87$.

[2] Badan Ketahanan Pangan. 2019. Direktori Perkembangan Konsumsi Pangan. Badan Ketahanan Pangan. Jakarta.

[3] Direktorat Gizi Departemen Kesehatan. 2010. Daftar Komposisi Bahan Makanan. Departemen Kesehatan. Jakarta

[4] Suprijatna, E., Atmomarsono, U dan R. Kartasujana. 2005. Ilmu Dasar Ternak Unggas. Penerbit Penebar Swadaya. Jakarta.

[5] Anthony T. 1997. Food Poisoning. Departement of Biochemistry Colorado Estate University. New York.

[6] Magdalena, Natadiputri F dan Purwadaria T., 2013. Pemanfaatan produk alami sebagai pakan fungsional. WARTAZOA Vol. 23 No. 1

[7] Ajileye, O. O., E. M. Obuotor., E. O. Akinkunmi, and M. A. Aderogba. 2015. Isolation and Characterization of Antioxidant and Antimicrobial Compounds from Anacardium occidentale L. (Anacardiaceae) Leaf Extract. Journal of King Saud University. 27(3): 244-252. 
[8] Leitão, N. C. M. C. S., G. H. C. Prado., P. C. Veggi., M. A. A. Meireles, and C. G. Pereira. 2013. Anacardium occidentale L. leaves extraction via SFE: global yields, extraction kinetics, mathematical modeling and economic evaluation. The Journal of Supercritical Fluids. 78: 114-123.

[9] Varghese, J., V. K. Tumkur., V. Ballal, and G. S. Bhat. 2013. Antimicrobial effect of Anacardium occidentale leaf extract against pathogens causing periodontal disease. Advances in Bioscience and Biotechnology. 4: 15-18.

[10] Setiawan, H., L. B. Utami, dan M. Zulfikar. 2018. Serbuk Daun Jambu Biji Memperbaiki Performans Pertumbuhan dan Morfologi Duodenum Ayam Jawa Super. Jurnal Veteriner. 19(4): 554-567.

[11] Mawaddah. , H. Setiawan, dan H. T. S. S. G. Saragih. 2020. Aktivitas Ekstrak Etanolik Daun Jambu Mete terhadap Otot Pectoralis Thoracicus Ayam Jawa Super. Jurnal Peternakan Indonesia. 22 (1): 8o-88.

[12] PT Charoen Pokphand Indonesia. Tbk. 2006. Manual Broiler Manajemen CP 707. Jakarta.

[13] Soeparno, 1994. Ilmu dan Teknologi Daging Edisi II. Gadjah Mada University Press. Yogyakarta

[14] Badan Standarisasi Nasional [BSN]. 2009. SNI 3924:2009. Mutu karkas dan daging ayam. Badan Standarisasi Nasional. Bogor.

[15] Scott, M.L.,M.C. Neisheim and R.J. Young. 1982. Nutrition of the Chicken. $3^{\text {rd }}$ Ed. M.L. Scott and Associates. Itacha. New York.

[16] Witantra. 2011. Pengaruh Pemberian Lisin dan Metionin terhadap Persentase Karkas dan Lemak Abdominal pada Ayam Pedaging Asal Induk Bibit Muda dan Induk Bibit Tua. Artikel Ilmiah. Universitas Airlangga. Surabaya.

[17] Khothijah dkk. (2021)

[18] Anggorodi, R. 1994. Ilmu Makanan Ternak Umum, Gramedia. Jakarta.

[19] Trisna, A., Roeswandy, dan M. E. Hutasoit. 2008. Penggunaan Tepung Biji Markisa Terhadap Pertumbuhan Itik Peking Umur 1-56 hari. Jurnal Agribisnis Peternakan. 4: 1-5.

[20] Anggorodi, H. R. 2004. Ilmu Makanan Ternak Umum. Gramedia, Jakarta.

[21] Scanes, C. G.,G. BRANT, M.E. ESMINGER. 2004. poultry science. 4 th ed. new jersey, usa: pearson/prentice hall.

[22] Wahyudi, I., Yanti, Rr., dan Santosa, P, E. 2015. Pengaruh Pemberian Ekstrak Daun Binahong (Anredera cordifolia Ten Steenis) dalam Air Minum terhadap Bobot Hidup, Bobot Karkas dan Giblet Broiler. Jurnal Ilmiah Peternakan Terpadu. 3(2):20-26.

[23] Wahyudi, I., Yanti, Rr., dan Santosa, P, E. 2015. Pengaruh Pemberian Ekstrak Daun Binahong (Anredera cordifolia Ten Steenis) dalam Air Minum terhadap Bobot Hidup, Bobot Karkas dan Giblet Broiler. Jurnal Ilmiah Peternakan Terpadu. 3(2):20-26.

[24] Mugiyono, S. 2001. Pengaruh campuran pakan komersil dan dedak padi yang ditambah $\mathrm{CaCO}_{3}$ dan premix terhadap pertumbuhan ayam kampung periode starter. Jurnal Agrisistem. 2 (1): 17-25.

[25] Wulandari, W.A. 2010. Kajian karakteristik biologis broiler. Bogor: Sekolah Pascasarjana, Institut Pertanian Bogor. Bogor.

[26] Fenita,Y., Warnoto, dan A. Nopis. 2010. Pengaruh Pemberian Air Buah Mengkudu (Morinda citrifolia L.) terhadap Kualitas Karkas Ayam Broiler. Jurnal Sain Peternakan Indonesia, 6(2): 143-150.

[27] Salam, S., A. Fatahilah., D. Sunarti dan Isroli. 2013. Bobot karkas dan lemak abdominal broiler yang diberi tepung jintan hitam (Nigella sativa) dalam ransum selama musim panas. Jurnal Sains Peternakan, 11 (2): 84-89.

[28] Suprayitno dan M. Indradji. 2007. Efektivitas Pemberian Ekstrak Temulawak (Curcumae xanthoriza) dan Kunyit (Curcumae domestica) dan sebagai Immunostimulator Flu Burung pada Ayam Niaga Pedaging. J. Animal Production.9: 178-183.

[29] Suharti, S., Banowati, A., Hermana, W., dan Wiryawan, K.G. 2008. Komposisi dan Kandungan Kolesterol Karkas Ayam Broiler Diare yang Diberi Tepung Daun Salam (Syzygium polyanthum Wight) dalam Ransum. Media Peternakan. 31(2): 138-145.

[30] Rasyaf, M. 2010. Beternak Ayam Pedaging. Penebar Swadaya. Jakarta.

[31] Aziz, A., 2005. Pengaruh Pembatasan Ransum dengan Pengaturan Waktu Makan pada Siang Maupun Malam Hari Terhadap Karkas Ayam Broiler Jantan. Jurnal ilmiah ilmu peternakan. VII/2 : 72-78.

[32] Suprijatna, E., Atmomarsono, U dan R. Kartasujana. 2005. Ilmu Dasar Ternak Unggas. Penerbit Penebar Swadaya. Jakarta.

[33] Mashur., D,A, Candra., J, Maratun., S,T, Kunti., O, Dina. 2020. Potensi Daun Ashitaba (Angelica keiskei) sebagai Sumber Fotobiotik dalam Pakan terhadap Produksi Lemak Abdominal Ayam Broiler. Jurnal Vitek Bidang Kedokteran Hewan. 10: 38-43 (41).

[34] Budiarto, M, Arif. Yuniwarti, E, Y, W, dan Isroli. 2016. Pengaruh Pemberian Tepung Daun Jati Belanda (Guazuma ulmifolia L.) dalam Pakan terhadap Kadar Trigliserida Darah dan Lemak Abdominal Ayam Broiler. Buletin Anatomi dan Fisiologi. Universitas Diponegoro. 1(1) : 43-47.

[35] Pratikno, H. 2011. Lemak abdominal ayam broiler (Gallus sp.) karena pengaruh ekstrak kunyit (Curcuma domestica Vahl). BIOMA. 13(1): 17-24. 
[36] Nggena, M., F. M. S. Telupere, dan N. T. Tiba. 2019. Kajian Pertumbuhan dan Kadar Kolestrol Broiler yang Disubstitusi Tepung Daun Lamtoro (Leucaena leucocephala) Terfermentasi $\mathrm{EM}_{4}$ dalam Ransum Basal. Program Studi Ilmu Peternakan. Universitas Nusa Cendana. Kupang.

[37] Resnawati. 2004. Bobot Potongan Karkas dan Lemak Abdomen Ayam Ras Pedaging yang Diberi Ransum Mengandung Tepung Cacing Tanah. Prociding Seminar Nasional Teknologi Peternakan dan Veteriner. Balai Penelitian Ternak. Bogor.

[38] Susanto. B. 2019. Substitusi Tepung Ikan dengan Tepung Jeroan Ikan Patin (Pangasius hypopthalmus) dalam Ransum terhadap Karkas Ayam Ras Pedaging Fase Finisher. Skripsi. Fakultas Pertanian dan Peternakan. Universitas Islam Negeri Sultan Syarif Kasim Riau. Pekanbaru.

[39] Subekti. K, H. Abbas dan K. A. Zura. 2012. Kualitas Karkas (Berat Karkas, Persentase Karkas dan Lemak Abdomen) Ayam Broiler yang Diberi Kombinasi CPO (Crude Palm Oil) dan Vitamin C (Ascorbic Acid) dalam Ransum sebagai Anti Stress. Fakultas Peternakan. Universitas Andalas. Vol. 14: 447-453 (3).

[40] Rizal, Y., 2006, Ilmu Nutrisi Unggas. Andalas University Press. Padang. 